\title{
Cinco livros do Modernismo brasileiro
}

\author{
José Paulo Paes
}

O presente texto foi especialmente escrito para uma história das literaturas latino-americanas, planejada pela prof" Ana Pizzarro sob os auspícios da Associação Internacional de Ljteratura Comparada. A coordenação da parte brasileira da referida história está a cargo dos profs. Alfredo Bosi, Antonio Candido e Roberto Schwarz. Limitações de espaço, próprias de uma obra panorâmica dessa natureza, ajudam a explicar - caráter esquemático do presente texto e a sua destinação a um público não estritamente brasileiro, o predomínio nele do aspecto informativo sobre $o$ interpretativo.

Na perspectiva de uma história da invenção de formas literárias, as chamadas grandes obras do Modernismo brasileiro, por meritórias que possam ser, necessariamente aparecem como algo tardias e/ou epigonais em relação às do seu epicentro francês, aquele "umbigo do mundo", a que se referia Paulo Prado no prefácio do Pau-brasil. Os treze anos que separam a realização da Semana de Arte Moderna de 1922 do lançamento do manifesto futurista de 1909 , ponto de partida da longa série de proclamaçōes vanguardeiras das três primeiras décadas do século, mostram não ter sido assim tão instantânea quanto pretendia Antônio de Alcântara Machado a repercussão, no Brasil, do "movimento reacionário europeu". Por outro lado, uma vista de olhos ao índice de nomes citados por Mário de Andrade na sua súmula da poética de 22, A Escrava que não é Isaura, dá logo a perceber tampouco terem sido "independentes entre si" os movimentos desencadeados pela "mesma ânsia de renovação" artística, tanto "na Europa quanto nas duas Americas"1. As frases entre aspas são ainda de Alcântara Machado, cujo testemunho acerca das idéias e das ilusôes do grupo modernista de São Paulo é particularmente significativo por vir de um dos seus primeiros $e$ mais bem dotados seguidores.

Todavia, à luz de um projeto de cultura brasileira que começa a se esboçar já no século XVI, a atualidade e a pertinência das principais obras do movimento de 22 passam a primeiro plano, fazendo recuar para os fundos de quadro, por secundária, a questão de sua dívida para com modelos ou antecedentes europeus. Talvez se possa ver, como teorização pioneira desse atê então informulado projeto de cultura brasileira, a "lei da obnubilação" formulada por Araripe Júnior num dos aditamentos à sua biografia de Gregorio de Matos (1893). Lei que consistiria em o colono arribado à América portuguesa ter de alijar a sua "bagagem de homem civilizado" e se animalizar, "descendo a escala do progresso psicologico" - isto $\epsilon$, revertendo ao estado de barbárie, - a fim de poder "concorrer com os primitivos íncolas"2, mais bem adaptados do que ele ao habitat selvagem. Outra instância do mesmo esforço de teorização aflora na barbarização empática que, através de

1 MACHADO, A.A. Cavaquinho e saxofone (solos), 1926-1935. Rio de Janeiro, José Olympio, 1940. p. 306.

2 COUTINHO, A. ed. Obra crtica de Araripe Júnior. Rio de Janeiro, Casa de Rui Barbosa, 1960. v. II, p. 479. 
uma citação de Taine, se propõe Euclides da Cunha logo à entrada de Os Sertōes. Na noção tainiana do "narrador sincero" empenhado em "sentir como bárbaro, entre os bárbaros" (para pôr em vernáculo o que Euclides deixou em francês, sem se dar muita conta da incongruencia desse respeito tăo pouco bárbaro pela letra do texto alheio), encontrava ele o paradigma do seu proprio esforço de, para além das deformaçóes da sua ideologia positivista, discernir a verdadeira semântica social de Canudos.

Obnubilação, barbarização - outros tantos nomes para aquele processo de mestiçagem ou sincretismo que, num vislumbre de rara lucidez, Sílvio Romero enxergou como básico na formação não s 6 da gente mas principalmente da cultura brasileira. Com os modernistas de 22, o conceito de mestiçagem cultural chegaria ao grau máximo de lucidez, transformando-se inclusive em bandeira de luta, isso desde $o$ Manifesto da poesia pau-brasil de 1924, com a sua enfase no "bárbaro e nosso", até o Manifesto antropófago de 1928, onde o "bárbaro tecnizado de Keyserling"3 é dado como ponto de chegada da Revolução Caraiba. Nessa promoção culta da barbárie, foi decisivo o impulso aqui recebido da moda primitivista que assolou a Europa a partir do começo do século e que se veiculou nos seus movimentos artísticos de vanguarda. Na gênese do

Entretanto, ao aderir de corpo e alma à voga do primitivo, os vanguardistas de 22 não estavam apenas copiando mais uma moda européia. Estavam era tentando descobrir a identidade brasileira por um processo de retomada cultural... cubismo, a escultura da África negra teve, como se sabe, importância comparável à da lição geometrizante de Cézanne. A poesia primitiva africana, por sua vez, transitou dos expressionistas alemāes para os dadaístas de Zurique que, nas noitadas do Cabare Voltaire, se compraziam em declamá-la ao som de tambores. $O$ Brasil não ficou esquecido nessa voga: em 1918 Paris ouvia'a execução de dois poemas tupis musicados para vozes femininas e batidas de mãos por Darius Milhaud, o mesmo Milhaud responsável pela partitura de L'Homme et son désir, texto teatral de Paul Claudel ambientado na floresta amaz6́nica e encenado em 1921 pelo Bale Sueco4. Convém ainda não esquecer as estreitas ligaçōes dos modernistas de São Paulo com Blaise Cendrars, cuja Anthologie Nègre de 1918 foi um dos marcos do neoprimitivismo literário, a que ele não deixou de incorporar o exótico brasileiro através de poemas e textos em prosa sobre as experiências de suas viagens ao País.

Entretanto, ao aderir de corpo e alma à voga do primitivo, os vanguardistas de 22 nâo estavam apenas copiando mais uma moda europeia. Estavam era tentando descobrir a identidade brasileira por um processo de retomada cultural, que Oswald de Andrade explicitou no Manifesto antrop6fago: "Sem nós a Europa não teria sequer a sua pobre declaração dos direitos do homem". Referia-se ele obviamente ao mito do bom selvagem inspirado pelo índio americano a Montaigne e Rousseau e que o neoprimitivismo se encarregou de pór outra vez em circulação. Antonio Candido acentuou a legitimidade dessa retomada ao observar que "no Brasil, as culturas primitivas se misturam à vida cotidiana ou são reminiscências ainda vivas de um passado recente", pelo que as "terriveis ousadias" sugeridas a artistas plásticos como Picasso e Brancusi ou a poetas como Max Jacob e Tristan Tzara pelas deformaçōes e/ou simplificações expressivas da arte primitiva são "mais coerentes com a nossa herança cultural do que com a deles"5. Primitivo era então um rótulo muito amplo. Abrangia não

3 ANDRADE, O. Manifesto da poesia pau-brasil. Manifesto antrop6fago. In:-_- . Do pau-brasil à antropofogia e d̀s utopias. Rio, Civilização Brasileira/MEC, 1972. (manifestos, teses de concurso e ensaios). A "Falaçăo" de Pau-brasil É uma versão resumida e modificada do Manifesto da poesia pau-brasil; nas citaçōes que se seguem, ambas as versöes sāo utilizadas.

4 Apud Serge Fauchereau, La révolution cubiste. Paris, Denoel, 1982. p. 91.

5 CANDIDO, A. Literatura e sociedade: estudos de teoria e histbria literária. São Paulo, Nacional, 1965. p. 145. 
apenas culturas tradicionais já extintas como a etrusca, a egf́pcia e a da Grécia pré-clássica, ou ainda vivas, como as da África negra, da Oceania e das Américas, mas também a cultura popular contemporânea, especialmente as expressőes de arte naive tăo caras aos cubistas, fossem os quadros do Douanier Rousseau ou os espetáculos de circo, a música de cafe-concerto ou o romance-folhetim, a cuja leitura Apollinaire, aficcionado de Fantomas, reputava "uma ocupação poética do mais alto interesse" $"$. O primitivo, outrossim, se aproximava da criança na medida em que com ela partilhava da mesma mentalidade pre-16gica, categoria de base da antropologia de Lévy-Brühl bem conhecida de Mário e de Oswald de Andrade. A

infantilidade $\epsilon$, reconhecidamente, um dos traços da arte moderna. No dadaísmo, por exemplo, Renato Poggioli discerniu uma "intransigente puerilidade, um extremo infantilismo" "7 a seu ver, a exaltação da espontaneidade infantil, característica de boa parte da arte de vanguarda, aponta para uma regressão psicologica ligada de perto à relação conflituosa entre filhos e pais. Relação que o choque de geraçōes proprio da dinâmica da historia literária vai constituir em dialética, ao passadismo dos pais ou antecessores opondo-se ao vanguardismo dos filhos ou sucessores. Dessa síndrome regressiva da vanguarda são componentes essenciais 0 gosto pela arte como jogo ou brincadeira, donde contestá-la pela sátira e a paródia à seriedade da arte acadêmica, tanto quanto a nostalgia da inocência ou pureza da infância, a que busca remontar pela recusa da má-consciência que considera inseparável da lógica e da moral burguesas.

Curioso observar que, no Modernismo brasileiro, a volta ao primitivo e ao infantil configurava um itinerário inverso ao dos seus modelos estrangeiros. Por ter como motivaçăo o fastio, quando não a desistência dos valores da civilização ocidental, $o$ primitivismo das vanguardas européias punha à mostra o seu carater de fuga ao familiar rumo do exótico. $O$ dos modernistas brasileiros de 22 significava, ao contrário, a busca das rafizes remotas, $e$ supostamente mais autênticas, de sua propria cultura. Daí que a regressão que eles gostosamente empreendiam em verso e prosa fosse menos a uma infância individual do que a uma infância nacional. Antes de evocar no

Primeiro Caderno do Aluno de Poesias, de 1927, a sua meninice paulistana, Oswald de Andrade revisitara antes, em Pau-brasil, de 1925, a infância histórica de sua pátria com a "alegria da ignorância que descobre"8. Também a pletora de adivinhas, frases-feitas, parlendas e trava-línguas do folclore infantil usada por Mário de Andrade em Macunatima para narrar as andanças do seu herói-síntese ecoa-lhe, isomorficamente, a matreirice de moleque, primeiro das trilhas do mato, depois das ruas de São Paulo.

$O$ remonte às origens históricas da nacionalidade, ao momento mítico do encontro do índio com o europeu, equivalia a um banho lustral para a recuperação daquele "estado de inocência" do primitivo e da criança que um dos incisos do Manifesto da poesia pau-brasil de 1924 aproximava do estado de graça. Como toda inocência a posteriori, a do primitivismo modernista tinha o sentido crítico de uma redução fenomenológica. Sentido aliás discernível desde o indianismo neoclássico, onde a ingenuidade do iroquês de Voltaire pode ser vista como uma espécie de estratagema eidético para desmascaramento de embustes ideológicos, tanto quanto o era, no indianismo romântico, a contraposição da nobreza moral do

6 FAUCHEREAU, op. cit., p. 107.

7 POGGIOLI, R. The theory of the avant-garde. Trad. G. Fitzgerald. Cambridge, Mass., Harvard University Press, 1968. p. 62. Ver tambem p. 35 e 107.

8 ANDRADE, O. Falaçáo. In: CAMPOS, H. org. e introd. Poesias reunidas $O$. Andrade. São Paulo, Difel, 1966. p.68. 
selvagem à amoralidade utilitária de seus colonizadores. Assim também, chegados ao presente depois de sua viagem de ida e volta ao Cabralismo, puderam os modernistas de São Paulo, com a "alegria da ignorância que descobre", iniciar a crítica da herança colonial que ainda lhes embargava o passo à altura de 1922. Então, nas comemoraçôes do primeiro centenário da independência política do Brasil, a retórica cívica, pela sua própria vacuidade, pôs bem à mostra o atraso material e cultural em que vegetava o País. Voltado, porém, mais para o estético do que para o político ou o social (e o esquematismo da hermenêutica histórico-sociológica do Retrato do Brasil, de Paulo Prado, antes parece confirmar do que desmentir pela exceção um pendor generalizado), o grupo de 22 s6́ se ocupou das mazelas culturais decorrentes dessa incômoda herança. Empenhou-se em denunciar-lhe a bacharelice, 0 "lado doutor" da pedagogia jesuíta continuado pelas faculdades de Direito, e o verbalismo que the é congênito, o "falar difícil" da língua culta submissa à norma gramatical lusitana. Foi neste ponto que, espicaçados pelas naturais afinidades do primisivo com o popular exploradas pelo cubismo europeu, os primitivistas brasileiros deram o melhor de si ao renovar radicalmente o código literário. Voltando as costas à erudição e à gramática, foram buscar no melting pot da cultura popular do campo e da cidade a língua "sem erudição", a língua "natural e neológica" que, forjada pela "contribuição milionária de todos os erros", veio enfim amalgamar sem fissuras o "como falamos" ao "como somos" e dar voz própria ao homem brasileiro. No domínio da língua, foi sem dúvida com o Modernismo que a literatura brasileira conquistou em definitivo a sua autonomia.

Para concluir a dialética das vanguardas, que pedem sempre ao passado remoto o aval das inovaçōes com que contestam o passado imediato, alcança explicar satisfatoriamente o paradoxo de os primitivistas de 22, tão nostálgicos dos tempos cabralinos, terem não obstante os olhos voltados para o futuro. Tanto assim que, fazendo tábula rasa do que ficou a meio caminho desses dois extremos - o mejo caminho do período colonial e do período que, embora se pretendesse já nacional, guardava tantos resquícios daquele -

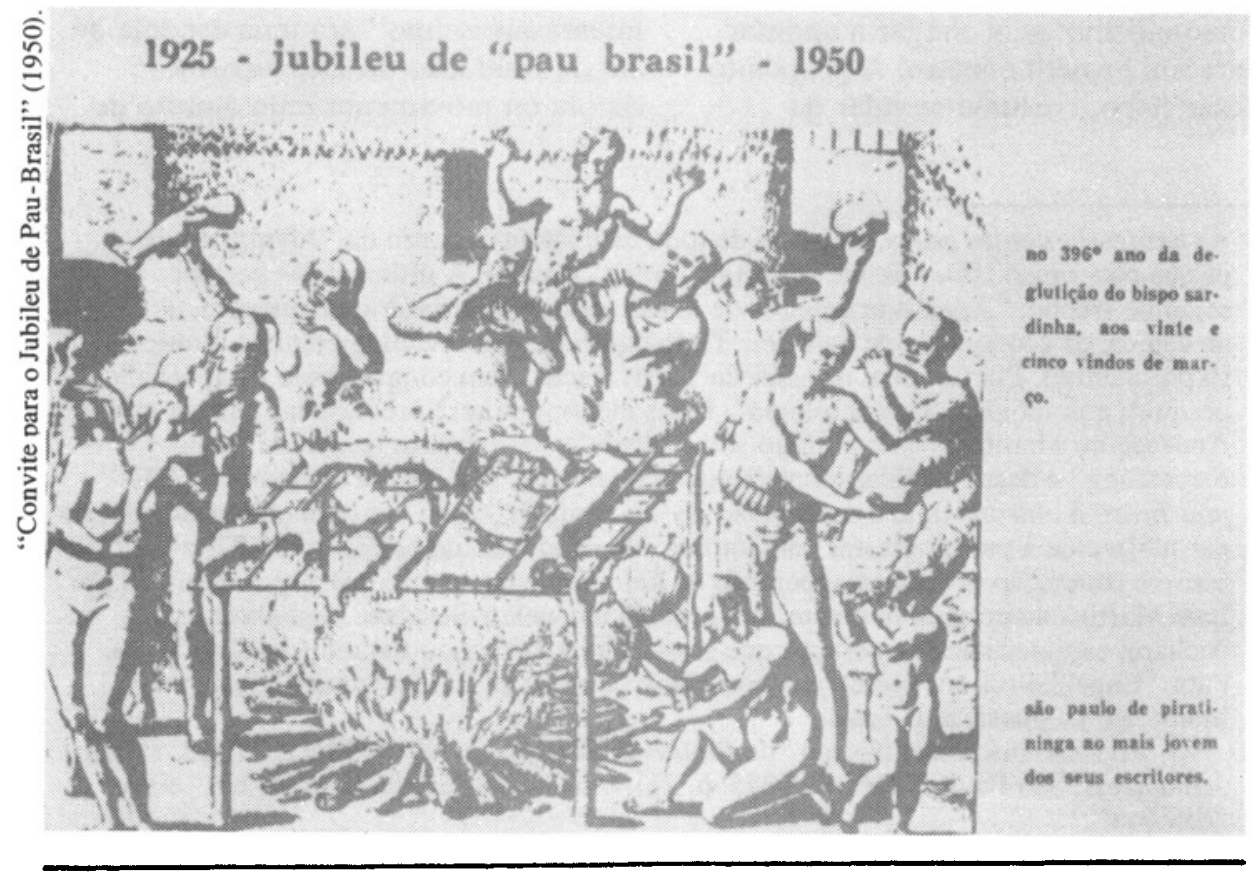


propuseram-se eles a conjugar sem contradição a inocência da barbárie reconquistada à sabedoria pragmática da tecnologia da modernidade para poderem ser com isso os "brasileiros da nossa epoca"9.

É de se esperar que esta brevíssima incursão pelos pressupostos do que se pocieria chamar uma teoria do Modernismo de 22 tenha bastado para pôr em relevo quão grande foi a refração sofrida pelas influências das vanguardas européias, ao passarem pelo prisma de um projeto obnubilador ou antropofágico de cultura brasileira que, ao menos virtualmente, era anterior à revoluçāo modernista. Cumpre ter sempre em mente o grau dessa refração para se poder estimar no seu justo valor o contributo das principais obras geradas pelo movimento. Ao limitar a cinco o número das que irăo ser aqui discutidas, atentou-se sobretudo no seu caráter de abridoras de caminhos novos, caminhos que obras posteriores dos mesmos ou de outros autores, ainda que de mérito comparável, só fizeram alargar.

\section{I}

Em Paulicéia Desvairada (1922), de Mário de Andrade, cronologicamente o primeiro livro modernista publicado no Brasil, a refração naturalizadora se confina ainda ao domínio do personalismo, sem chegar a apontar para um projeto comum. A propósito desse livro, costuma-se falar da influência do unanimismo de

Verhaeren e Jules Romains, perceptível também em Ha uma Gota de Sangue em cada Poema... (1917), o livro de estréia do autor. No caso de Paulicéia Desvairada, a influência deles sofre uma refração que se faz sentir, quando mais não seja, na intromissão constante do Eu lírico num tipo de discurso que, por aspirar à expressão daqueles "sentimentos unânimes" 10 citados por Romains no título do seu artigo-manifesto de 1905, refugia do pessoal. Sendo Verhaeren e Rcmains poetas da fase intervalar entre o fim do Simbolismo e o advento das vanguardas, não estranha que, ao escolher um verso do primeiro para epigrafar o "Prefácio interessantíssimo" de Paulicéia Desvairada, Mário de Andrade se desculpasse ali de "estar tão atrasado dos movimentos artísticos atuais". De fato, em comparação com o atualizado elenco de autores modernisticamente canônicos citados em A Escrava que não é Isaura, os trazidos à colação no prefácio de Paulicéia Desvairada, onde Marinetti e Cocteau ainda se acotovelam ecleticamente com Victor Hugo e Bilac, mostram que a modernice dele estava em processo de formação.

Escrito em parágrafos curtos, de linguagem incisiva, como convém à dos manifestos, o "Prefácio interessantíssimo" era uma espécie de ata de fundação do Desvairismo, escola ou movimento cujo âmbito de

9 As expressōes entre aspas, ao longo de todo este parágrafo, são do "Manifesto da poesia pau-brasil" (Oswald de Andrade, op. cit., nota 3). A última delas pertence ao seguinte trecho: "Apenas brasileiros de nossa época. O necessário de química, de mecânica, de economia e de balística. Tudo digerido. Sem meeting cultural. Práticos. Experimentais. Poetas. Sem reminiscências livrescas. Sem compreensão de apoio. Sem pesquisa etimologica. Sem ontologia". Estas idéias, que serão retomadas por Oswald de Andrade no Manifesto antropófago sob a fórmula do "bárbaro tecnizado de Keyserling" e desenvolvidas amplamente em "A crise da filosofia messiânica" (Do pau-brasil à antropofagia e às utopias, op. cit., nota 3), têm a ver com o conflito filhos $\mathrm{X}$ pai subjacente à psicologia das vanguardas. No Modernismo brasileiro de 22, o conflito assume conotação própria: a superação da polaridade bacharel $x$ patriarca apontada por Luis Martins na geração abolicionista-republicana pela polaridade engenheiro $x$ bacharel característica da geração que assistiu à (e participou da) industrialização do País. "Engenheiros em vez de jurisconsultos" $e$ o que significativamente reclama o Manifesto da poesia pau-brasil.

10 No "Prefácio interessantíssimo" de Paulicéia desvairada (in: ANDRADE, M. Poesias completas. São Paulo, Martins, 1955. p. 21), o poeta fala expressamente em "alma coletiva". 
atuação se esgotou ali. Para justificar o título do livro e o nome da escola a que servia de ilustração prática, explicava o poeta: "Quando sinto a impulsão lírica escrevo sem pensar tudo o que o meu inconsciente me grita". Não é difícil perceber nisto o magisterio do automatismo psíquico iniciado pelos dadaístas e sistematizado depois pelos surrealistas, assim como o culto literário do desvario - alegorizada por uma maiúscula simbolista, "minha Loucura" será a musa do poeta ao longo do livro - tem possivelmente algo a ver com as sete "chansons de fou" da primeira parte de Les Villes tentaculaires de Verhaeren, confessadamente $o$ autor de cabeceira de Mário de Andrade no ano em que compôs Paulicéia Desvairada ${ }^{11}$. Ao apresentar-se "como louco" no "Prefácio interessantíssimo", o poeta aceitava por antecipação o rótulo depreciativo que the seria pespegado pelos filisteus. A eles haveria por certo de parecer adoidada e incompreensível a "ordem imprevista das comoções, das associaçōes de imagens, de contactos exteriores" que, para poder cantar o "seu inconsciente", Mário de Andrade registrava nos seus versos, tão discrepantes de tudo quanto havia sido feito até ali na poesia brasileira, ainda que parecessem tímidos em comparação com os primeiros poemas dadaístas. Tivera ele um antegosto da reação filistina quando do escândalo provocado pelo aparecimento, em 1921, do artigo de Oswald de Andrade "O meu poeta futurista", no qual era reproduzido um dos poemas de Paulicéia Desvairada. O "Prefácio interessantíssimo" faz referência aos inconvenientes pessoais trazidos a Mário de Andrade por esse escândalo, e a virulência com que, em peças como "Ode ao burguês", "A caçada", "Colloque sentimental" e "As enfibraturas do Ipiranga" é versada a oposição entre artista e burguês, revela tratar-se menos da exploração de um topos da arte de vanguarda que de um desabafo de ordem íntima.
O desvario da linguagem inovadora do poeta paralelizava o desvario da vida trepidante da metrópole por ele celebrada. Mediante o uso sistemático do que, no "Prefácio interessantíssimo", ele chamava de "verso harmônico" e "polifonia poética" - um verso formado de palavras futuristicamente em liberdade, sem ligação gramatical entre si, a vibrarem no seu insulamento como a harmonia de um acorde irresoluto; uma polifonia verbal conseguida pela superposição de frases soltas, as mais das vezes elípticas por escamoteamento do verbo - tentava ele suscitar o mesmo efeito de simultaneidade do "tumulto desordenado das muitas idéias" a se atropelarem no cérebro num momento de especial comoção. Para dar conta de tal comoção e do tumulto interior por ela engendrado, abusava o poeta inclusive de notações gráficas como as reticências e o ponto de exclamação, de uso extensivo já entre os simbolistas. Só que, em Paulicéia Desvairada, as reticências visavam a dar força de ressonância à palavra em si, liberta das sujeições sintáticas, enquanto o ponto de exclamação era a imagem icônica de uma subjetividade teatral a admirar-se de suas próprias visōes e introvisōes.

A simetria, desde o nível de uma teoria da composição, entre a tumultuosa interioridade do poeta e a não menos tumultuosa exterioridade da sua Paulicéia anuncia-se no verso de abertura do primeiro poema do livro:

\section{São Paulo! comoção da minha vida...}

Trata-se, contudo, de uma simetria dialética, inscrita mais na ordem da polaridade de contrários que do alinhamento de semelhanças. Se, pelo que dão a entender poemas de efusão lírica como "Inspiração", "Paisagem no 1" ou "Tristura", é de amor a relação entre o poeta e a cidade, outros poemas como "Os cortejos", "A escalada" ou "Ode ao burguês" mostram a dose de rancor subjacente a tal efusão. $O$ tema da metrópole

11 Cf. M. Bandeira. org. e pref. Cartas de Mário de Andrade a Manuel Bandeira. Rio, Simões, 1958. p. 293. 
moderna aparece em Paulicéia

Desvairada com o mesmo sentido que tem na poesia de Baudelaire e

Reverdy, onde, segundo Mortimer

Guiney, $\varepsilon$ "símbolo da matéria fria, estática e indiferente, criada pelo homem na sua tentativa de estabelecer uma ponte entre si e o mundo exterior (...) do insucesso da humanidade ante o problema da incompatibilidade entre espirito e matéria"12. Essa relação problemática é marcada, na estilística de inovação de Paulicéia Desvairada, pela freqüência com que advérbios e infinitivos são substantivados pela anteposição de artigo: "os sempres", "os aplaudires", "os tambéns", "os muito-ao-longes", "nos jamais" etc. Aponta semelhante recurso para uma especie de reificação da circunstância, indicativa de um malogro do $\mathrm{Eu} \mathrm{em}$ avir-se com ela, de um desencontro entre a magnitude do desejo e a escala do possível. Outrossim, o fato de a substantivação se fazer sempre no plural envolve a idéia de fatal e desalentadora repetitividade, alem de evidentemente contrastar com a singularidade do Eu: na gramática poética do livro, a primeira pessoa do singular e suas marcas, pronomes e flexōes verbais, corporificam a interioridade do poeta, ao passo que a terceira do plural é a máscara da cidade e de seus mandatários:

Pauliceia - a grande boca de mil dentes.

A essa pessoa múltipla, ou "alma coletiva", diz respeito a pluralização constante de substantivos quase sempre abstratos por via dos quais, ao mesmo tempo em que mapeia os seus dilemas interiores, vai o poeta desenhando o perfil moral da sua desvairada Paulicéia. Perfil de cunho fortemente crítico nos poemas que tematizam o conflito entre os valores antagônicos do Eu e do Eles. É o caso de "A escalada", cuja metáfora de base, a cidade como um "morro de ambiçôes", se prolonga na do calvário ("crucificaçōes da honra") que o poeta, falando consigo mesmo numa segunda pessoa de tom ironicamente admonitório, incita-se a escalar após ter-se livrado dos "fardos" de seus escrúpulos idealistas ("Estes mil quilos de crença") para, Hermes-Pança, poder chegar ele também ao "sol sonante" dos plutocratas. Em "Tietê", o rio da outrora aventura bandeirante aparece degradado em mero local de competiçōes de nataçāo: o advérbio "esperiamente", no segundo verso, deriva do nome de um clube esportivo então freqüentado por imigrantes enricados ou descendentes deles, a julgar pelos dois versos em italiano na última estrofe.

A imagem da Paulicéia, como espaco de opulência financeira e refinamento mundano, iterativa em "Rua de São Bento", "O domador", "A caçada", "Paisagem no 2", condensa-se no refrão "- Futilidade, civilização" que fecha cada uma das quatro estrofes de "Domingo", com o seu staccato de notaçóes coloquiais compondo um quadro sarcasticamente descritivo. $O$ mesmo registro sarcástico, que chega à virulência política em "O rebanho" e "Ode ao burguês", pervaga de começo a fim "As enfibraturas do Ipiranga", o texto mais ambicioso do livro. Nesse "oratório profano", os vários estratos da sociedade paulistana - escritores e artistas acadêmicos, milionários e burgueses, operariado e gente pobre - alternam coralmente suas vozes com as das Juvenilidades Auriverdes, ou seja, o grupo modernista, e da Minha Loucura, figuração simbólica da individualidade do poeta. Lançando mão de recursos como a monotonia das rimas repetitivas ou o contraste entre formulas prosaicas e metáforas alambicadas, "As enfibraturas do Ipiranga"' compilam um catálogo de chavôes do senso comum, da patriotada e do academismo, de par com certos cacoetes do próprio idioleto modernista, para fazer ouvir em plenitude o registro paródico que será a marca de fábrica do Modernismo brasileiro em sua fase heroica.

12 GUINEY, M. Cubisme et litterature. Genebra, Georg \& Cie S.A., 1972. p. 81. 
O caráter coral do último poema de Paulicéia Desvairada, discrepante do personalismo da maior parte dos que o antecedem, aponta já para um projeto transpessoal, de grupo. Em pólo oposto, "Colloque sentimental" nos dá a expressāo mais reveladora da dialética do amor:rancor próprio do subjetivo de Paulicéia Desvairada, assim como a de amor:humor o será do visual de Pau-brasil. Na mesma linha do "Noturno" do Cambuci, cuja condição de bairro popular é conotada pelo grito do vendedor de batata assada e pelo violāo do "mulato cor de oiro", a condição aristocrática de Higienópolis nos anos 20 ressalta dos flagrantes ora descritivos ora alusivos com que "Colloque sentimental" lhe fixa, em meio à noite paulistana, $o$ brilho das mansões com, lá dentro, as casacas de seus condes e os ombros nus, o rouge pecaminoso e adulterino de suas grandes damas. Há uma ostensiva nota de crítica social nesses flagrantes - como o "rio de lágrimas" proletárias escorrendo de sob as portas das mansões -, mas ela não obsta a que o elocutor do poema, identificado pelo "eu" elíptico do primeiro verso, confesse no mesmo tom expiatório de "Religião", poema que se segue imediatamente a "Colloque sentimental", sua invencível atração por aquelas "Babilônias dos [seus] desejos mais baixos" que, embora sentindo-se excluído, ele culposamente percorre com os "pés chagados nos espinhos das calçadas". Não vem ao caso apontar eventuais nexos de simetria das equações amor:rancor e amor:humor com as diferenças do status social dos autores de Paulicéia Desvairada e Pau-brasil à altura em que escreviam esses livros inaugurais. Nem explicar por aí eventuais atitudes de estranhamento ou à-vontade em relação ao apoio recebido pelo grupo de 22 do patriciado paulista, que tantas vezes $o$ acolheu em suas mansões de Higienópolis. O que importa, acima de tudo, é a diversidade dos resultados literários das ditas equaçōes e o alargamento assim trazido ao espectro da expressão modernista.

III

Conquanto o famoso epigrama "amor:humor" só vá aparecer no Primeiro Caderno do Aluno de Poesias Oswald de Andrade (1927) o qual, não obstante o título, é na realidade o segundo livro de poemas do autor - ele já preside implicitamente a poética de Pau-brasil (1925). Não tanto a teorizada nos versículos de "Falação", variante condensada do Manifesto pau-brasil, como a dedutível dos poemas que a ela se seguem. A extremada concisão desses poemas levou Paulo Prado, no prefácio do livro, a chamar-lhes "comprimidos, minutos de poesia", glosando assim, talvez sem o saber, um dito de Tristan Tzara, que falou em "comprimido de linguagem" 13 ao referir-se ao lugar comum usado pelos poetas cubistas com propósito semelhante ao das colagens da segunda fase, a fase sintética, da pintura cubista. $O$ magistério do cubismo literário e pictórico $€$ de resto perceptível em $P$ au-brasil, não mais, porém, do que o alto grau de inventividade demonstrado pelo seu autor no aproveitar-lhe as instigações para fundar uma "poética da radicalidade" 14 com justeza ali apontada por Haroldo de Campos. Para se ter a medida dessa radicalidade, s ilustrativo cotejar os poemas brasileiros de Feuilles de route, de Blaise Cendrars ${ }^{15}$, com peças de temas semelhantes de Pau-brasil. Nestas, muito mais que naqueles, a redução ao mínimo dos nexos gramaticais, a constante elipse do verbo, os deslocamentos qualificativos e os jogos

13 FAUCHEREAU, op. cit., p. 138.

14 CAMPOS, H. org. Poesias reunidas ... op. cit., (ver introdução).

15 Cotejo ainda mais ilustrativo se feito com base na tradução desses poemas para o português realizada por Teresa Thiériot que consta em: Blaise Cendrars, Etc... etc... (um livro 100\% brasileiro). São Paulo, Perspectiva, 1976. 
paronomásicos e alusivos não só dinamizam a elocução como a fazem distanciar-se do lógico rumo ao analógico.

Além de estimular-lhe a capacidade de fixar em linhas rápidas de caricatura o essencial do que pretendia

representar, a síntese cubista abriu os olhos do poeta de Pau-brasil para o espetáculo do cotidiano.

"Escapulário", a peça de abertura do livro, vale como uma espécie de sua divisa ou programa:

\section{No Pão de Açúcar \\ De Cada Dia \\ Dai-nos Senhor \\ A Poesia \\ De Cada dia}

Aí estão in nuce alguns dos principais artigos de fé da arte poética oswaldiana. A paródia do texto litúrgico é visualmente sublinhada pelo uso de maiúsculas de reverência, sendo que, em nível semântico, o jogo alusivo convida a ler o virtual por sob o literal: a poesia de cada dia é também o pão de cada dia. Não o pão tout court que mata a fome, mas o pão de massa mais fina que, além de matá-la, lisonjeia o paladar: mais bem se percebe a ironia desta complementação do utilitário pelo hedonístico ou estético quando se pensa na virtude da frugalidade tão encarecida nos textos de edificaçāo religiosa. Todavia, o fundamental é a paródia ser acionada pelo aproveitamento de um lugar comum da geografia turística nacional que, em outro poema do mesmo livro, "Noite no rio", assume também caráter litúrgico pela sua homologia de contornos com o manto triangular da Virgem tal como representada na iconografia: "O Pão de Açúcar/É Nossa Senhora da Aparecida/Coroada de luzes".

O lugar comum é a pedra de toque do cotidiano por cristalizar-lhe, numa fórmula ready-made, a consubstancial mesmice ou falta de rovidade: a vida de todos os dias como repetição, rotina. Situa-se ela, portanto, nos antípodas da literatura, a qual tem antes a ver com a novidade da matéria ou expressão, quer em prosa (novela vem de "nova") quer em verso (o poético é o contrário do prosaico). Daí que, ao privilegiar o lugar comum e ao tematizar o cotidiano, a poesia de Pau-brasil se colocasse

deliberadamente no campo da antiliteratura. Poder-se-ia inclusive considerá-la, historicamente, o avesso da dicção parnasiano-simbolista, onde linguagem e tema elevados eram de praxe e de rigor. Mas por sob a negatividade paródica de Pau-brasil corre um permanente fio de

positividade: humor é amor. Ao voltar-se para o cenário cotidiano, o poeta não quer vê-io com os olhos da rotina. Propõe-se antes vê-lo com os olhos novos da "ignorância que descobre", mesmo porque "a poesia é a descoberta/das coisas que eu nunca vi", liçāo por ele aprendida do seu filho de dez anos, conforme está dito num dos poemas do livro, 3 de maio. Ver o já-visto como nunca-visto equivale a inverter radicalmente as regras do jogo, fazendo do cotidiano o espaço da novidade e do literário o espaço da rotina ou convenção.

$O$ enternecimento irônico (amor:humor) com que o poeta se compraz em rever o dia-a-dia para revitalizar-lhe os estereótipos é típico da ignorância ou inocência assumida $a$ posteriori. Nela, à surpresa infantil com o nunca-visto, subjaz a má-consciência adulta do já-visto, donde a sua ironia ou duplicidade de visão. Ela dá sinal de si em "História

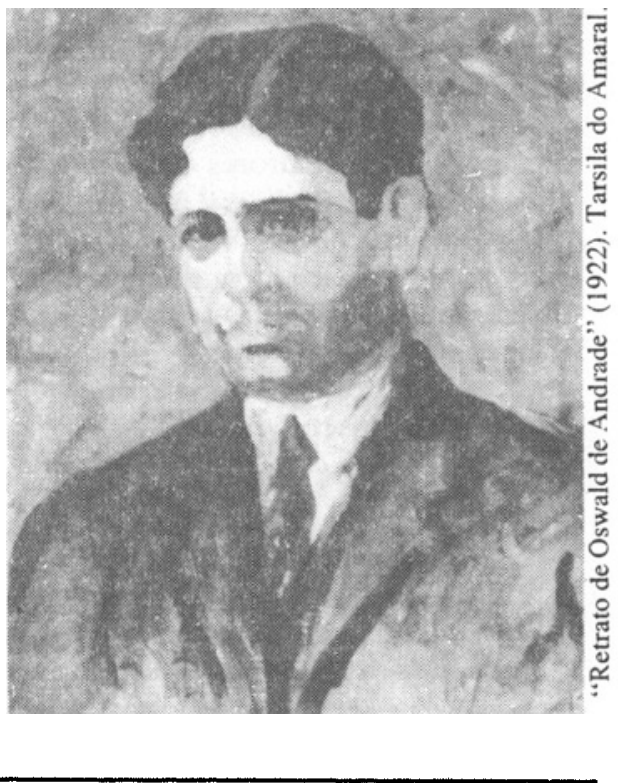


do Brasil", a primeira das nove secçōes temáticas em que se divide Pau-brasil. Ali, trechos de prosa de cronistas coloniais, Caminha, Gandavo, d'Abeville e outros, são dispostos em forma de versos a fim de melhor ressaltar o pitoresco do deslumbramento pueril deles ante às singularidades e maravilhas do Novo Mundo. Esta utilização da técnica de colagem é sui generis por utilizar material historiográfico em vez de material contemporâneo, os recortes de jornal, fragmentos de conversaçāo, letras de cançōes etc., a que os poetas cubistas costumavam recorrer. Digna de nota, ainda, a recorrência de técnica semelhante em "Secretário dos amantes". O título dessa sexta secção de Pau-brasil foi tirado das brochuras populares de modelos de cartas de amor, e os seis breves poemas que a compóem podem ser vistos como uma espécie de paródia das cantigas d'amigo: a elocução é de igual modo assumida pela mulher, mas a mistura coloquial de expressões de carinho com observações práticas ironiza em certa medida a sentimentalidade costumeira do gênero. Neste caso, também, limitou-se Oswald de Andrade a dar forma de versos a trechos de cartas que lhe foram escritas pela pintora Tarsila do Amaral, então sua mulher ${ }^{16}$.

Usada com freqüência ao longo do livro, a colagem, notadamente de textos de anúncios, serve a fins de sátira por assim dizer documental, já que, por cortejar o favor do público, o reclame acaba por lhe revelar obliquamente a psicologia e os valores. Entretanto, quando se avém com textos naifs, a sátira oswaldiana deixa entrever uma indisfarçável ponta de enternecimento com a ingenuidade popular. Foi o que, não sem the opor alguns reparos, assinalou Mário de Andrade em Pau-brasil: "O. de $A$. se aternurou sem crítica por tudo o que é do povo"17. Esse enternecimento paródico está por trás da fidelidade com que é registrada em "Carnaval" e "O ginásio", por exemplo, a linguagem a um só tempo empolada e canhestra das proclamaçōes dos ranchos cariocas e dos volantes de propaganda de espetáculos populares como o do "tenor boxeur Romão Gonçalves". É ela ainda que explica a atração, do mesmo poeta cosmopolita que em contrabando dirá trazer no coração "Uma saudade feliz/de Paris", pela simplicidade da vida nas cidadezinhas do interior de São Paulo e Minas Gerais celebradas em "RP 1" e "Roteiro das Minas". Uma delas lhe vai inspirar o admirável "ditirambo" ("Meu amor me ensinou a ser simples/Como um largo de igreja") e nos letreiros das modestas casas de comércio de outra "nova iguaçu", enxergará ele alvíssaras do país sem pecados sonhado pela nostalgia dos tempos idílicos do Cabralismo, assim reverentemente grafado com maiúscula inicial na abertura de "Falação". Na linguagem, nas festas e nos costumes da vida popular do seu tempo o poeta reencontra o mesmo bárbaro nosso das origens cabralinas. Pois este é o próprio genius loci a que devemos a originalidade nativa capaz de redimir-nos do pecado da adesáo acadêmica do Brasil doutor para que possamos ser enfim os brasileiros de nossa época.

É bem de ver que, em Pau-brasil, o pendor primitivista e popularesco convive, sem contradição, com o culto modernista do progresso. Culto que ressalta em aiguns dos poemas de "Lóide brasileiro", a última secção do livro: no "canto de regresso à pátria", parodiando Gonçalves Dias, diz-nos o poeta que deseja voltar para "o progresso de São Paulo", e em "Recife", tanto ou mais do que as relíquias históricas, encantam-no os guindastes e chaminés da cidade, "Baluarte do progresso". É menos insólita do que pode parecer esta simbiose da barbárie e do

16 Cf. AMARAL, A. Tarsila - sua obra e seu tempo. São Paulo, Perspectiva, 1975. v. I, p. 75.

17 Apud Telê Porto Ancona Lopez, Mário de Andrade: ramais e caminho. São Paulo, Duas Cidades, 1972. p. 170. 
primitivismo com o progresso e a tecnologia. Aos olhos dos defensores mais ferrenhos da cultura dita humanística, a idolatria moderna da técnica sempre se afigurou, no fundo, a emergência de uma nova barbárie. E se se tiver em mente que o Manifesto da poesia pau-brasil se volta sobretudo contra a erudição e a bacharelice "humanísticas" de nossa formação histórica, não fica difícil entender $O$ apreço de Oswald de Andrade, no Manifesto antropófago, pelo "bárbaro tecnizado de Keyserling".

Um último aspecto de Pau-brasil que não pode passar sem registro é a sua visualidade e, correlatamente, a sua impessoalidade, já que ali nos fala $o$ poeta menos de si que do mundo à sua volta. Isso mau grado ele se ter proposto, em "Falação", uma "perspectiva de outra ordem que a visual". Referia-se, no caso, ao visual meramente fotografico da "argúcia naturalista", em troca da qual aspirava à nova visualidade da "síntese" cubista. Esta, ele a soube realizar, pioneiramente e melhor do que ninguém entre nós, por via da feliz conjunção da parodia, da colagem e do lugar comum revitalizado, "a poesia de cada dia", no quadro de uma poética de amor:humor. E o contraste entre a impessoalidade dela e o personalismo subjetivo de Paulicéia Desvairada dá fé não apenas da amplitude do projeto modernista em sentido estrito como das futuras aporias da nossa modernidade em sentido lato.

\section{IV}

Quando se passa da poesia para o romance de Oswald de Andrade, está-se passando de arte que busca esconder a sua mestria por trás de uma estudada simplicidade para arte que timbra em alardear-se o tempo todo como tal, apontando um dedo enfático para a sua própna máscara ${ }^{18}$. Asceticamente, a poesia pau-brasil almejava ser uma simples "apresentação dos materiais" em estado bruto, no que se contrapunha, de caso pensado, à poesia sua antecessora "emaranhada na cultura" e nos "cipós das metrificaçōes"19. Já a prosa de arte das Memórias Sentimentais de João Miramar (1924) prazerosamente se entrega às "violências maravilhosas da cor", conforme lhe está dito no prefácio, de modo a năo deixar dúvidas quanto à sua primazia de iniciadora da expressão modernista em nossa ficção. A justificativa desta dualidade de posturas estilísticas talvez esteja na circunstância de, como poeta, Oswald de Andrade ter estreado já modernista, enquanto Os Condenados, seu primeiro romance, publicado embora no mesmo ano da Semana de Arte Moderna, é visivelmente um livro pré-modernista. $O$ "'gongorismo verbal da escrita" 20 nele denunciado por Antonio Candido o define desde logo como um produto típico do art nouveau literário.

À adjetivação frondosa de quem, por focalizar a vida sob as lentes de um patetismo à D'Annunzio, se esmerava em realçar-lhe operisticamente as tintas, sucede a preocupação do "estilo telegráfico e a metáfora lancinante" anunciados desde o prefácio das Memórias Sentimentais de Joâo Miramar como fruto da "nova revolução" em prol de "uma língua modernista". Língua que, distinguindo-se pela novidade desses recursos da tradição arte-novista, desta herdara contudo o mesmo impulso ornamental. Quando se fala em ornamento, está-se implicitamente falando em excesso ou

transbordamento do significante sobre o significado, como se aquele se tornasse em certa medida independente deste. No caso de Miramar, tal relativa independência é confirmada pelo fato de, após uma viagem a Paris onde travou conhecimento mais íntimo com as novas modas artísticas, ter o romancista modernizado radicalmente o estilo de uma primeira versão mais

18 Expressão usada por Roland Barthes algures em $O$ grau zero da escritura.

19 Frases de "Falação" em Pau-brasil ... op. cit.

20 CANDIDO, A. Brigada Ligeira. São Paulo, Martins, s.d. p. 16. 
conservadora do livro, datada de $1917^{21}$. Era como se, invertendo o exemplo clássico que Paulo Prado invocava no prefácio de Pau-brasil, para expressamente desmenti-lo com a novidade tanto de fundo quanto de forma da poesia ali enfeixada, o seu autor, agora doublé de romancista, passasse a fazer versos novos sobre pensamentos antigos.

Não é assim tão descabido falar em versos a propósito de Miramar. Na medida em que se distanciava do ideal de uma "prosa pura" sonhado por Antônio de Alcântara Machado, incorria ele no equívoco da "prosa lírica" que o mesmo Alcântara Machado verberara como prosa que "não é prosa"22. Salta à vista tender o estilo de Miramar mais à exuberância lírica do que à objetividade prosaica. Nele se multiplicam as metáforas de impacto ("o vento batia a madrugada como um marido"), as rimas e aliterações consecutivas ("sapos sapeiam sapas sopas"), as metonímias violentas ("sons lestos de campainhas ancoraram o navio"), os oxímoros ("escada subia quedas"), as onomatopéias semantizadas ("o grilo I Triste tris-tris-triste"), os lances trocadilhescos ("bandos de bondes iam para as bandas da Avenida"), os deslocamentos qualificativos ("as barbas alemãs de um médico"), as alterações de regência verbal ("malta escabriavam salas brancas"), as nominações grotescas ("Miss Piss", "Pindobaville") ${ }^{23}$. Mas o que particularmente se faz notar é o gosto futurista do telegráfico e do

Lá é evidentemente a Europa, a França em particular, de onde o

Brasil importava então quase todos os refinamentos modernos... neológico, um manifesto na sistemática omissão de conectivos gramaticais, em especial artigos, e o outro na freqüente verbalização de adjetivos ou substantivos

(norte-americanava, guardanapavam). Se aqueles outros recursos de expressão podem ser vistos como manifestaçōes mais ou menos gratuitas de ludismo poético, estes dois últimos estāo intimamente ligados à semântica do livro. $O$ telegráfico ecoa isomorficamente o tema da viagem, nele central, e da correlata dialética entre o Lá e o Cá emblematizada no nome do seu protagonista, um Miramar de olhos sempre postos no mar de embarques, nunca de desembarques. O neológico, por sua vez, articula a fala de um desejo que, na exasperada multiplicação dos signos da modernice cosmopolita de Lá, busca uma compensação simbólica para o provincianismo da atrasada vida de Cá. Lá é evidentemente a Europa, a França em particular, de onde o Brasil importava então quase todos os refinamentos modernos, entre eles a ânsia de uma liberdade sexual que Oswald de Andrade iria exprimir mais de uma vez nas suas inacabadas memórias Um Homem sem Profissão (1954): "Tudo isso vinha confirmar a idéia de liberdade sexual que doirava o meu sonho de viagem, longe da pátria estreita e mesquinha, daquele ambiente doméstico onde tudo era pecado. (...) Na Europa, o amor nunca foi pecado. Não era preciso matar para possuir uma mulher. Não havia lá sanções terríveis como aqui pelo crime de adultério ou seduçăo. Enfim o que existia era uma vida sexual satisfatória, consciente e livre" 24 .

Não é descabido trazer à colação este texto autobiográfico para iluminar aspectos do texto ficcional: um e outro coincidem repetidas vezes, como mostrará qualquer leitura comparativa de Um Homem sem Profissão e Miramar. Neste, após narrar a infância e adolescência do seu herói, demora-se o romancista em descrever-lhe a viagem pela Europa, de volta da qual Miramar desposa uma

21 Cf. AMARAE, A. op. cit., p. 77 e 99.

22 Cf. MACHADO, A. Cavaquinho e saxofone ... op. cit., p. 341.

23 ANDRADE, O. Memórias sentimentais de João Miramar. Rio de Janeiro, Civilização Brasileira, 1971. (Obras completas, $3^{\mathrm{a}}$ ed., v. II).—— Serafim Ponte Grande. Rio de Janeiro, Civilização Brasileira, 1971. (Obras completas, 2ª ed., v. II).

24 ANDRADE, O. Um homem sem profissäo: memórias e confissöes. Rio de Janeiro, José Olympio, 1954. p. 122. (1ำ v., 1890-1919, sob as ordens de mamãe). 
prima rica, herdeira de fazendas de cafe. O restante do livro $\epsilon$ consagrado a pormenorizar-lhe as aventuras extraconjugais e boêmias em São Paulo, Santos e Rio, culminadas no seu divórcio, a que se seguem as mortes sucessivas da sogra e da esposa. Este anticlímax faz da filha única de Miramar herdeira dos bens maternos e garante a ele a vida sem preocupaçōes materiais de que o seu hedonismo não podia abrir mão. Combinado à similitude de títulos, a menção do hedonismo traz à mente do leitor das Memórias Sentimentais de João Miramar a lembrança das Memórias Póstumas de Brás Cubas daquele Machado de Assis que, ao lado de Euclides da Cunha, era tudo quanto, na literatura brasileira, interessava ao autor de $U \boldsymbol{m}$ Homem sem Profisssāo, segundo ali confessa ${ }^{25}$. A despeito das extremadas diferenças de tempo histórico e projeto criativo, há algumas semelhanças entre os dois livros. Em Brás Cubas talvez aprendesse, Oswald de Andrade, a técnica dos capítulos curtos com títulos as mais das vezes irônicos utilizada em Miramar, depois em Serafim Ponte Grande (1933). E tanto o herói machadiano quanto o oswaldiano parecem ter sido talhados no mesmo pano para, cada qual à sua maneira, figurar o tipo do gozador elegante e cínico que, num texto autobiográfico, se distrai a fixar os ridículos, pecados e fraquezas alheios, por eles obliquamente justificando uma moral de interesse próprio. Brás Cubas se dá ao trabalho de explicitar as justificativas nas pachorrentas reflexōes a que naturalmente o convida o seu eterno 6 cio de defunto sem mais nada por viver; as tropelias boêmias de João Miramar não lhe deixam tempo livre para refletir sobre elas, só para vivê-las; tire quem quiser a moral da fábula. Tirando-a, percebe-se que aponta menos para as feiçōes intemporais de um caráter à Teofrasto do que para o rosto histórico de um patriciado agrícola, cujo cosmopolitismo bem viajado mal the escondia a condição semicolonial.
Do que há de bifronte nesse rosto histórico dá testemunho imediato, no plano das homologias, o transbordo da modernice mais que futurista do estilo de Miramar por sobre a convencionalidade da sua matéria ficcional, que faz lembrar a do romance cosmopolita e fútil de Morand, Dekobra ou Guido de Verona. Com duas ressalvas: a de o trabalho de linguagem de Miramar ser muito mais avançado do ponto de vista estético, e a de ter sido livro escrito num diapasão satírico que não teme ir até o bufo. Estas ressalvas apontam, por sua vez, para duas direçōes diversas, identificadas no mea culpa que Oswald de Andrade antepôs ao Serafim Ponte Grande como prefácio. Penitencia-se ele de, nesse romance e no Miramar, ter feito literatura de vanguarda na ilusão burguesa de "colocar a literatura nova-rica da semicolônia ao lado dos custosos surrealismos imperialistas". Mas reconhece, porém, no seu vanguardismo, "uma fonte sadia, o sarcasmo", que lhe permitiu servir "à burguesia sem nela crer". Com isso, podia aliviadamente concluir, no mesmo prefácio, terem sido seus dois romances modernistas não apenas um "índice cretino, sentimental e poético" das veleidades cosmopolitas da burguesia cafeeira de São Paulo, mas também o seu "necrológio". Um necrol6gio em grande estilo, ainda que feito de vers nouveaux sur des pensers antiques.

VI

No "Prefácio interessantíssimo", cuja publicação antecedeu de dois anos a do Manifesto da poesia pau-brasil, Mário de Andrade ja caracterizava os modernistas como os "primitivos de uma nova era". Mas fazia questão de ressaltar que, ao escrever os poemas de Paulicéia Desvairada, buscara fugir do "primitivismo vesgo e insincero" para só reter, das hipóteses acerca dos "primitivos das eras passadas", aquilo que o pudesse levar a uma "expressão mais humana e livre de arte". Seis anos depois, com a

25 Ibid., p. 119. 
publicação de Macunaíma, parece ele ter deixado definitivamente de parte quaisquer reservas anteriores para mergulhar fundo na voga primitivista. Era o que dava a entender a circunstância de a figura do herói do livro e grande parte das peripécias ali narradas terem sido tomadas de empréstimo à mitologia ameríndia, a par de o registro coloquial em que foi escrito estilizar a fala popular.

Macunaíma apareceu no mesmo ano em que Oswald de Andrade divulgava (maio de 1928) o seu Manifesto antropófago. Mário de Andrade sublinhou, na época, tratar-se de mera coincidência, visto a primeira versão do livro datar de 1926; o certo, no entanto, é que ele respondia ao mesmo clima de idéias do manifesto, afora o qual, aliás, Oswald de Andrade não produziu nada de reconhecivelmente antropófago. Em matéria de criação literária, portanto, a Antropofagia se limitou praticamente a Macunaíma e Cobra Norato, poema de Raul Bopp, só em 1931 recolhido em livro.

A designação de "rapsódia", introduzida a partir da segunda edição de Macunaíma, para definir-lhe a forma narrativa, pode ser entendida, literariamente, no sentido de imitação do estilo de compor dos rapsodos ou cantadores populares e, musicalmente,

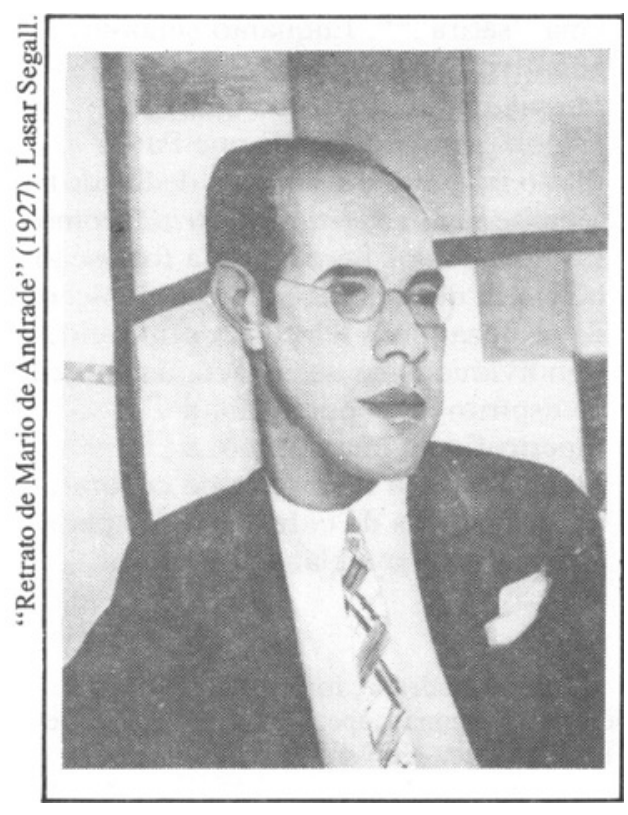

no sentido de fantasia livre e exuberante sobre motivos folclóricos. As duas acepçōes são pertinentes. A primeira $e$ ilustrada, na linguagem do livro, pela freqüência de enumerações, refrões, frases rimadas ou aliterativas; pelo aproveitamento sistemático de locuções tradicionais e parlendas infantis; pelo recurso iterativo ao provérbio e à hipérbole; pelo à-vontade com que o mágico e o real se entremesclam. Tudo isso dentro do espírito lúdico de quem se encantasse mais com o fluxo da própria fala do que com a coerência da exposição, espírito no qual se faz reconhecível um pendor retórico herdado pelo homem do povo de seus antepassados índios. Ao dar cidadania literária à fala popular, tentava Mário de Andrade, como ele próprio diz na "Carta pras icamiabas" (cap. IX), transpor o fosso que separava o "brasileiro falado" do "português escrito". Por isso não há em Macunaíma a diferença de registro elocucionário que havia na ficção regionalista, sua antecessora, entre personagem e narrador: este assume, sem mais diferença de estatuto social, a voz e a persona daquele.

Tampouco se percebem aqui os propósitos de registro localista que animavam o regionalismo. A fantasia rapsódica combina agora livremente entre si, na mesma tapeçaria de deliberado desenho transregional, motivos folclóricos provindos das diversas regiōes do País. Desse transregionalismo dão prova, no nível da efabulação (onde, por repetitivas, assumem categoria de procedimento formal), as correrias do herói e seus perseguidores e/ou perseguidos por todos os quadrantes do País, numa movimentação cuja rapidez fabulosa oblitera as distâncias de ordem quer geográfica quer cultural. A exuberância da fantasia rapsódica ultrapassa livremente os limites da paráfrase para invadir os da invenção: o rol de episódios míticos tradicionais é enriquecido de episódios novos, mas consubstanciais deles, como se a inventiva do escritor se folclorizasse por contaminação. É o que avulta nos lances em que usos e artefatos da vida moderna são explicados por via mítica 
(por exemplo, o caso da onça virada em automóvel no cap. XIV), à maneira dos contos etiológicos. Dada a anterioridade temporal do texto de Macunaíma, seria descabido querer ver em lances tais ilustrações fabulares de postulados do Manifesto antropófago. Mas não há como fugir à evidência de terem sido inspirados pela mesma preocupação de estabelecer o nexo de consubstancialidade entre primitivo e atual que, para os modernistas de 22 , se fazia o penhor de serem eles os verdadeiros "brasileiros de nossa época".

Deste prisma, a transposição das aventuras de um herói folclórico da longínqua Amazônia para as ruas metropolitanas de São Paulo ganha outro sentido que não o de mera exploração das possibilidades cômicas do anacronismo. Como se sabe, Mário de Andrade foi buscar, às lendas ameríndias colhidas pelo etnógrafo alemão Koch-Grünberg no norte do Brasil e na Venezuela, o material de base da sua rapsódia, que posteriormente enriqueceria com elementos de outras numerosas fontes e com matéria de sua própria invenção. O enredo de Macunaíma gira em torno da viagem empreendida pelo herói epônimo e seus irmãos Jiguê e Maanape, desde a beira do Uraricoera, onde ele havia nascido e onde se tornara imperador da Mata-Virgem, depois do seu casamento com $\mathrm{Ci}$, rainha das amazonas, até São Paulo. O motivo da viagem é encontrar a muiraquitã ou talismã da felicidade que ele perdera e que lhe fora presenteado por $\mathrm{Ci}$ antes de ela, inconformada com a morte de seu filho com Macunaíma, subir para o céu e converter-se numa estrela. $O$ talismã extraviado estava agora em poder do mascate Venceslau Pietro Pietra, avatar do gigante Piaimã. Depois de numerosas aventuras picarescas por São Paulo e Rio, onde se passa o principal da narrativa, $o$ herói consegue recuperar a muiraquitã e volta para o mato de onde viera.

Mas a sua tribo havia sido entrementes liquidada por uma epidemia e seus dois irmãos também não tardam a morrer. Solitário e abúlico, Macunaíma já não tem interesse pelas coisas. Nova perda do talismã por culpa do engodo de uma uiara que o atraíra para dentro d'água tira-lhe o último meio de devolver algum sentido à sua vida, pelo que ele, despedindo-se do mundo, ascende ao céu e se transforma numa constelação.

Ao escolher para protagonista de sua rapsódia um herói folclórico cujo nome significava "o grande malvado" e em cuja personalidade a soma dos defeitos sobrepujava bastante a das qualidades, Mário de Andrade não escondia um propósito de crítica que o subtítulo de "o herói sem nenhum caráter" dado a ela só fazia realçar. De começo, alegando tratar-se de um "livro de pura brincadeira", negou-lhe a condição de símbolo do homo brasilicus nele vista por Tristão de Ataíde, um dos seus primeiros resenhadores. Isso porque, no entender do autor de Macunaíma, símbolo implicava uma "totalidade psicológica" de todo ausente do seu herói ou anti-herói, de quem tirara "propositalmente o lado bom do brasileiro" a fim de poder torná-lo uma "sátira"26. Enquanto símbolo negativo, o protagonista de

Macunaíma compendia os traços psicológicos essenciais que Paulo Prado (a quem o livro está dedicado) recenseou em Retrato do Brasil como resultantes dos percalços da formação histórica da nacionalidade: a ambição da riqueza fácil, a lascívia sem freio, o individualismo anárquico, a carência de espírito de cooperação, a hipertrofia da imaginação, a loquacidade, a facilidade de decorar, as alternativas de entusiasmo e apatia, a indolência, a melancolia difusa.

26 As' citações entre aspas, de declarações de Mário de Andrade, foram colhidas nos escólios de ordem crítica incluídas por Telê Porto Ancona Lopez na 2ª e $3^{a}$ partes de sua edição crítica de Macunaíma. Rio, LCT, (Biblioteca Universitária de Literatura Brasileira).p. 265 e 336. 
Traços eles todos negativos, próprios de uma visão crítica do caráter e da realidade nacionais que timbrava em distanciar-se o quanto pudesse da ufania a que desde sempre se apegara certo patriotismo tanto mais inócuo quanto acrítico. Se bem semelhante catálogo de traços esteja longe de dar conta da personalidade contraditória e múltipla de Macunaíma - seria preciso acrescentar-lhe no mínimo os traços conexos de esperteza, prazer de mistificar e dom da improvisação são o bastante para destacar, na criaçāo individual, o débito para com um ideário de grupo. $O$ lado menino ou moleque do herói mário-andradino inculca-lhe de pronto uma figuração da irreverência infanto-juvenil com que as vanguardas costumam reptar a respeitabilidade do Establishment.

No artigo em que recenseou

Macunatma quando do seu lançamento em 1928, lembrava Tristão de Ataíde, a propósito da "Carta pras icamiabas", as Cartas persas 27 . Mas isso de passagem, sem se demorar no paralelo.

Desenvolvido, ele levaria necessariamente a uma similitude de funções entre as proezas de Macunaíma em São Paulo, clímax da narrativa, e o confronto iluminista civilização $x$ primitividade de que L'ingénu de Voltaire é o paradigma no terreno da prosa de ficção. Tambem a gesta paulistana do herói do Uraricoera serve para pôr em relevo mais a presteza com que ele se integra no mundo tecnológico do que sua estranheza ante os prodígios dele. Mal chegado à Paulicéia, ei-lo que decifra, à luz do pensamento mítico, um mistério que o pensamento logico não conseguira nunca decifrar: "A Máquina era que matava os homens porém os homens é que mandavam na Máquina". Isso acontecia simplesmente porque eles "não tinham feito dela uma Iara explicável mas, apenas uma realidade do mundo"28. Vale dizer: tinham-na deixado ficar na ordem desumana do real em vez de integra-la na ordem humana do mítico. $E$ da superioridade desta sobre aquela é sinal seguro a facilidade com que, logo em seguida a essas reflexōes, Macunaíma consegue transformar magicamente seu irmão Jiguê numa máquina-telefone a fim de ligar "Pros cabarés encomendando lagosta e francesa". Não só alcança, pois, um domínio demiúrgico da máquina como a pōe a serviço da satisfação imediata dos seus desejos, em vez de ficar à mercê do capricho dela, como os civilizados.

À primeira vista, este passo, e outros semelhantes, parecem indicar a recorrência, sob a forma de realização fictiva, do ideal do selvagem tecnizado de Keyserling que o Manifesto antropofago propunha sob a forma de postulado. A suposição teria a respaldá-la a reconhecida influência das idéias de Keyserling acerca do homem novo das Américas sobre o pensamento de Mário de Andrade. Delas, porem, as que mais de perto lhe interessaram foram as relativas à significatividade da indolência tropical (donde o moto famoso de Macunaíma: "Ai que preguiça") e da necessidade de sintonia entre o "Können" e o "Sein", entre desenvolvimento material e desenvolvimento espiritual ${ }^{29}$. Elas o levaram a uma crítica da noção de progresso, principalmente tecnológico, em funçāo da incompatibilidade de valores entre civilizaçāo européia e civilizaçōes tropicais. A falta de caráter do brasileiro, personificada por Macunaíma, adviria da sua insistência em fugir dos valores telúricos do tropico onde vive e em tentar adaptar-se, com isso se descaracterizando, aos valores de uma civilização não-tropical como a européia. Essa traição ao genius loci está alegoricamente representada em dois episódios do livro. No capítulo VIII, o herói, conquanto se houvesse comprometido em desposar uma das filhas de Vei, figuração

27 Ibid., p. 338.

28 Id. ibid., p. 38.

29 LOPEZ, T.P.A. Mário de Andrade: ramais ... op. cit., p. 111-16. 
mitológica do Sol, acaba se enrabichando por uma varina, isto é, uma portuguesa vendedora de peixe. E no capítulo XVIII, último do livro, ele vence o receio da água fria para atirar-se nos braços da Uiara da lagoa: quando volta à margem, está todo desfigurado. O significado de ambos os episódios foi explicado mais tarde por Mário de Andrade. No primeiro, ao recusar "uma das filhas da luz", Macunaíma (e com ele o Brasil) renegava o exemplo "das grandes civilizações tropicais, China, Índia, Peru, México, Egito, filhas do calor" para se amulherar equivocadamente com "o Portugal que nos herdou os princípios cristãos-europeus". No outro episódio, Vei ou "a região quente solar" se vinga da traição contra ela cometida fazendo "aparecer a uiara que destroça Macunaíma". E este não consegue realizar-se, "adquirir um caráter", pelo que, frustrado, "vai pro césu, viver "o brilho inútil das estrelas" "30.

Já não se está mais, como se vê, no clima de otimismo utópico do segundo manifesto de Oswald de Andrade, com a sua Revolução Caraíba promovida pelo bárbaro tecnizado que antropofagicamente aproveitaria, do progresso europeu, so $a$

maquinaria, deixando-lhe de parte as idéias e as outras paralisias. Dir-se-ia que o desfecho melancólico da fábula de Macunaíma, com o seu anticlímax de derrota e desistência, leva em direção oposta. Configura antes o epitáfio do sonho antropófago, a sua autocrítica antecipada, essa fábula do índio dominador das máquinas da urbe industrial que, por não se encontrar mais a gosto nela nem na selva natal a que baldadamente regressa, desiste de viver. No que lembra madame Bovary, menos, herói sem nenhum caráter que $\hat{\epsilon}$, a grandeza moral dela. E como a Antropofagia assinala o fim do ciclo histórico do Modernismo de 22, Macunatma vale implicitamente por um balanço das suas consecuçōes, de que é uma das mais altas, tanto quanto de suas ilusões, a que serve de esplêndido mausoléu.
VI

Antônio Alcântara Machado fez parte do grupo da Revista de Antropofagia, mas o seu compromisso com a moda primitivista, pelo que dele dão notícia os contos de Brás, Bexiga e Barra Funda (1927), parece ter sido sui generis. Talvez nem conviesse falar de primitivismo no seu caso, não fosse a circunstância de o rótulo também se poder aplicar às manifestações mais ingênuas da vida popular contemporânea: como já se disse, ela tinha tanto interesse para os cubistas franceses quanto a dos povos "selvagens" propriamente ditos. Ao enfileirar os nomes dos três bairros pobres de São Paulo, onde se fixaram os imigrantes italianos que não foram para a lavoura de café ou dela conseguiram alforriar-se, o título do primeiro livro de contos de Alcântara Machado já punha de manifesto suas intenções, de resto confirmadas na dedicatória dele ao "triunfo dos novos mamalucos", entre os quais estavam incluídos os modernistas Menotti del Picchia, Anita Malfatti e Victor Brecheret. Explicava o prefácio do livro que os novos mamalucos ou "intalianinhos" resultavam do ulterior ingresso, na obra de miscigenação das "três raças tristes" formadoras da nacionalidade brasileira, da nova raça "alegre" vinda da Itália no bojo dos transatlânticos modernos.

Alegria e modernidade eram ingredientes canônicos do movimento de 22, mas, a julgar pela representação desfavorável do imigrante italiano na prosa de ficção de Oswald e Mário de Andrade, nâo o era a simpatia para com os novos mamalucos e seus maiores. Em Miramar, o "intalianinho" Chelinini acaba por se revelar um escroque que ascende socialmente através de casamento de interesse com a sogra do protagonista; mais adiante, italianos enriquecidos no comércio e na indústria vão aparecer mancomunados a agiotas "turcos" para, com financiar-lhe a estroinice dos filhos ou genros-famílias como o próprio

30 ANDRADE, M. Macunatma, op. cit., p. 325. 
Miramar, levarem o patriciado cafeeiro à ruína. Em Macunatma, por sua vez, o ogre ou vilão Piaimã assume o nome e a personalidade do italiano Venceslau Pietro Pietra, regatão ou mascate dos rios amazonenses que vem roubar a um filho da terra seu bem mais precioso, a muiraquitā da felicidade.

Nos contos de Alcântara Machado, os italianos e os "intalianinhos" são vistos por outra 6tica. A minuciosa atenção posta pelo contista no registrar-lhes os torneios de expressäo, o modo de vestir e de comportar-se, os ambientes onde viviam e conviviam, as metas e ambiçōes que Ihes norteavam a conduta, revela por si só, para além da escrupulosidade do simples reporter sem "partido nem ideal", que, no prefácio do Bras, Bexiga e Barra Funda, ele diz ser uma indisfarçável empatia de visão. Esta se voltava menos para imigrantes bem sucedidos como o cav. uff. Salvatore Melli, o industrial do conto "A sociedade", do que para gente humilde como o garoto de rua de "Gaetaninho", a costureirinha de "Carmela", o cobrador de ônibus de "Tiro de guerra no 35", o barbeiro de "Amor e sangue", a menina pobre de "Lisetta". o órfāo matreiro de "Notas biograficas do novo deputado" e assim por diante. Nāo é argumento contra a autenticidade da empatia de visão tais "aspectos da vida trabalhadeira" dos ítalo-brasileiros (a frase aspeada $\epsilon$ ainda do prefácio do livro) terem sido observados sob a lente da caricatura, do outro lado da qual se poderia discernir, igualmente deformado pelo vidro de aumento, 0 olhar de superioridade entre compassiva e curiosa do paulista bem-nascido. $O$ mesmo traço caricatural está presente nos contos de Laranja da China (1928), cujos personagens nada têm de ítalo-paulistas, mas ostentam sobrenomes lidimamente portugueses.
O gosto da caricatura era indissociável do espírito de 22 e Alcântara Machado o cultivou regularmente nos seus contos, nas crónicas de viagem de Pathe-Baby (1926) e nos artigos de jornal postumamente reunidos em Cavaquinho e Saxofone (1940). Num desses artigos, importantes pelo que dão a conhecer de suas opiniốes acerca da literatura e da vida, ele se debruça sobre a arte de Voltolino, caricaturista ligado ao grupo modernista. Ao analisá-la parece estar falando de sua propria arte de contista, como quando observa que Voltolino, por ter o "lápis desgracioso (...) caricaturava melhor os humildes", em especial os da colónia ítalo-paulista a que pertencia e onde se travava a "luta surda (...) entre os que para cá vieram enriquecer trazendo no fundo da trouxa, entre roupas remendadas e caçarolas furadas, todo o peso das tradiçóes de sua raça, e os filhos que deles nasceram aqui, livres dos preconceitos ancestrais, crescendo e se afirmando brasileiros em absoluta identidade com o solo e com o meio"31.

O lápis de caricaturista de Alcântara Machado era também desgracioso nạ medida em que fugia de caso pensado da sedução arte-novista do ornamento, a que pela sua própria exuberância, folclórico-coloquial num caso, mais-do-que-futurista noutro, nem Macunatma nem Miramar souberam esquivar-se. Diferentemente deles, 0 narrador de Brás, Bexiga e Barra Funda cultivava a virtude da "secura telegrafica" e a punha a serviço da "obra literária de movimento"32 que ele via confundir-se vantajosamente com a reportagem. Daí não temer apresentar os seus contos como "um jornal" que se contentava em apenas noticiar a vida: "Não comenta. Não discute. Não aprofunda"33. Num outro artigo de Cavaquinho e Saxofone Alcântara Machado opóe o romancista ao repórter para tomar decididamente o partido deste último:

31 MACHADO, A.A. Cavaquinho e saxofone ... op. cit., p. 250-51.

32 Ibid., p. 379.

33 Id. Brás, Bexiga e Barra Funda/Laranja da China. São Paulo, Martins, s.d. p. 31. 
"O romancista está espiando para dentro, bem no fundo. A vida que vive na luz 6 o repórter o único a fixar. Fixar por um minuto"34. $O$ minuto de vida $e$ fixado nos contos de Brás, Bexiga e Barra Funda por uma técnica de síntese que parece haver recrutado seus recursos na caricatura, no jornalismo e no cinema. Da primeira vem a economia de traços com que o caráter de cada personagem é esboçado; do segundo, a fatualidade do enfoque e a direitura do modo de narrar; do último, a montagem da efabulação em curtos blocos ou tomadas descontínuos. A técnica narrativa de Alcântara Machado deixaria inclusive uma marca indelevel no conto brasileiro, rastreável desde Marques Rebelo ate Dalton Trevisan.

Mas o essencial a destacar na citaçäo há pouco feita do texto sobre

Voltolino e a luta surda travada entre o imigrante italiano e os

"intalianinhos" dele aqui nascidos.

Não só porque ilustra outra instância do conflito filhos $x$ pai, típico da arte de vanguarda em geral e do Modernismo de 22 em particular, como porque traz outra vez à baila o tópico da obnubilação ou barbarização, da mestiçagem ou antropofagia cultural, que $e ́$ o ponto de fuga de todo o projeto modernista. Desse tópico, o último conto de Brás, Bexiga e Barra Funda constitui uma boa ilustração: o barbeiro Zampinetti vai abandonando o seu antigo chauvinismo italiano à medida que enriquece em São Paulo; termina por ser cabo eleitoral do PRP e por se naturalizar brasileiro tão logo seu filho Bruno se forma em Direito.

A imigração italiana assinalou, no campo, o fim do trabalho escravo e, na cidade, $o$ crescimento da indústria, a que forneceu primeiro mão-de-obra e mais tarde alguns dos seus capitães na figura de imigrantes aqui enriquecidos. Num dos artigos de Cavaquinho e Saxofone, ao mesmo tempo que reconhece esse contributo, Alcântara Machado cuida de sublinhar, não fosse paulista de primeira hora: "A mão de obra em parte $\epsilon$ estrangeira. A iniciativa porem tem sido sempre paulista. (...) Os cueras somos nós paulistas. Basta atentar no nosso poder formidavel de absorção"35. $O$ "triunfo dos novos mamalucos" marcava, pois, uma vitória do genius loci que vinha coroar o processo histórico brasileiro inaugurando-lhe a fase propriamente sćculo XX, quando ao caldeamento das três raças tristes se veio juntar a alegria italiana. Era a liquidação da melancolia índia, do banzo africano e da saudade lusa, trindade colonial em que o busnlis parece estar no segundo membro. Isso porque, mesmo recalcado, $o$ ideal do embranquecimento crescente do brasileiro parece ter sempre estado subjacente ao sonho modernista: Macunaíma nasce preto, mas assim que pode se torna branco. Estaria aí uma das razōes inconfessas da empatia de Alcântara Machado pelos novos mamalucos... brancos? E pergunta que permanece em aberto $e$ quem se disponha algum dia a fechá-la não poderá dispensar-se de ler, em Cavaquinho e Saxofone, os três artigos em que o autor anotou suas entusiasmadas impressões da Argentina. Num deles, significativamente intitulado "Onde o homem o é", ocorre esta passagem não menos significativa: "O branco nāo quer se tisnar de negro nem de amarelo e repele, com indisfarçável repugnância, convencido da sua superioridade, a parte negra e mulata da população brasileira. (...) Com sangue europeu do sul, do norte, inclusive judeu, aqui se está formando uma raça de ombros largos, estatura alta, saudável, ślida, igualmente feita para o trabalho e os chamados prazeres da vida".

34 MACHADO, A.A. loc. cit.

35 Op. cit., p. 74.

José Paulo Paes é ensaísta, poeta, tradutor e professor-visitante do IEA no segundo semestre de 1988 . 